\title{
PENGARUH EKSTENSIFIKASI PAJAK, KEPATUHAN WAJIB PAJAK, DAN PENCAIRAN TUNGGAKAN PAJAK TERHADAP PENERIMAAN PAJAK PENGHASILAN ORANG PRIBADI
}

\author{
MARIA LEVINA
}

Universitas Negeri Jakarta

\begin{abstract}
The purpose of this research is to examine the influence of extensification of tax, assessable compliance, and disbursement of tax arrears on tax revenue of personal income. This research uses secondary data with observation in KPP Pratama Jakarta Duren Sawit in 2012-2014. While the research uses multiple regression method to test the hypothesis at 5\% significance. From the analysis performed in this research, it can be concluded that extensification of tax and assessable compliance have significant influence to tax revenue of personal income. While disbursement of tax arrears has no significant influence to to tax revenue of personal income.
\end{abstract}

Keywords: Tax Extensification, Assessable Compliance, Disbursement of Tax Arrear,

Keywords : Tax, Extensification, Assessable Compliance, Disbursement of TaxArrears,Tax Revenue of Personal Income

\section{PENDAHULUAN}

Sumber penerimaan pendapatan negara adalah semua penerimaan negara yang berasal dari penerimaan perpajakan, penerimaan negara bukan pajak, serta penerimaan hibah dari dalam negeri dan luar negeri. Semua sumber penerimaan ini harus dijaga agar penerimaan negara tetap berada pada posisi yang stabil setiap tahunnya. Penerimaan negara melalui pajak memiliki andil yang besar dalam meningkatkan pendapatan negara. Jurnal IImiah Wahana Akuntansi
Berdasarkan data yang bersumber dari Departemen Keuangan, penerimaan pajak negara dari pajak penghasilan meningkat sebesar $8 \%$ dari tahun 2011 ke tahun 2012. Sedangkan dari tahun 2012 ke 2013 meningkat sebesar $15,8 \%$. Tetapi peningkatan tersebut tidak membuat target penerimaan pajak tercapai dalam 6 tahun belakangan ini. Pencapaian target penerimaan pajak yang terakhir terjadi pada tahun 2008 yaitu 6\% diatas target pencapaian. 
Pajak penghasilan ini terdiri dari PPh Migas dan non-Migas. Pada PPh non-Migas terdapat andil masyarakat yang cukup besar yaitu pada pajak orang pribadi, dimana semua pekerja yang mendapatkan penghasilan pada kriteria tertentu disebut sebagai wajib pajak dan mempunyai kewajiban untuk membayar pajak. Pajak inilah yang disebut pajak penghasilan orang pribadi. Wajib pajak orang pribadi yang memiliki penghasilan di atas penghasilan tidak kena pajak (PTKP) sampai tahun 2012 jumlahnya mencapai 60 juta orang. Namun, wajib pajak yang sudah memiliki NPWP baru mencapai 20 juta orang. Sedangkan wajib pajak yang membayar pajak baru sekitar 8,8 juta orang. Hal ini sungguh miris jika mengingat pajak yang dibayarkan oleh 8,8 juta orang digunakan untuk kepentingan negara yang berpenduduk 280 juta orang (www.pajak.go.id).

Dalam meningkatkan penerimaan pajak, pemerintah juga melakukan Ekstensifikasi Pajak. Ekstensifikasi pajak yang sudah dilakukan salah satunya yaitu dengan melakukan sensus pajak. Berdasarkan data dari Dirjen Pajak, hasil dari sensus yang dilaksanakan sejak tahun 2011, dapat menambah jumlah NPWP sebanyak 2 juta NPWP pada tahun 2012, jumlah ini naik secara signifikan. Ekstensifikasi juga dapat dilakukan dengan memberikan penyuluhan dan sosialisai mengenai peraturan perpajakan dan kemudahan dalam perpajakan sehingga pekerja aktif yang seharusnya menjadi wajib pajak dapat langsung mendaftarkan dirinya sebagai wajib pajak. Dengan dilakukannya ekstensifikasi pajak, jumlah wajib pajak yang bertambah diharapkan dapat menjadi wajib pajak yang patuh dalam memenuhi kewajibannya. Kategori patuh dalam perpajakan dapat dilihat dari berbagai macam pengukuran.

Menurut Agus D Martowardojo dikutip dari vivanews.com bila dibandingkan potensi pajak dari jumlah penduduk Indonesia yang berjumlah 
240 juta orang, kekayaan alam yang berlimpah, jumlah badan usaha yang lebih dari 20 juta, Indonesia bisa terus meningkatkan penerimaan negara dari pajak. Namun, Beliau mengatakan perlu dilakukan kerja keras dan cerdas serta langkah - langkah terobosan dibidang ekstensifikasi dan intensifikasi pemungutan pajak serta perbaikan secara fundamental dalam pelayanan kepada Wajib Pajak dan administrasi perpajakan.

Berdasarkan Laporan Keuangan Pemerintah Pusat (LKPP) tahun 2012, jumlah piutang pajak mencapai $\mathrm{Rp}$ 93,46 triliun, sedangkan pada tahun 2013, jumlah piutang pajak meningkat menjadi Rp103,24 triliun. Dari nilai piutang tersebut, piutang pajak yang berasal dari pajak penghasilan orang pribadi adalah sebesar Rp 2,6 triliun. Angka tersebut bukanlah angka yang kecil untuk tambahan penerimaan pajak penghasilan. Menurut Waluyo (2011:89), peningkatan jumlah tunggakan pajak tersebut seharusnya juga diimbangi dengan kegiatan pencairannya. Kegiatan pencarian yang dimaksud adalah kegiatan penagihan tunggakan pajak terhadap wajib pajak yang dilakukan oleh Juru Sita. Dirjen Pajak, Fuad Rahmany mengatakan jumlah wajib pajak yang memiliki tunggakan pajak mencapai jutaan orang sementara juru sita hanya sekita 300 orang, maka dari itu menurut Badan Pemeriksa Keuangan (BPK) menetapkan piutang bersih yang dapat direalisasikan hanya $\mathrm{Rp} 28,58$ triliun.

Tingginya angka piutang pajak tersebut menunjukkan bahwa masih banyak sekali wajib pajak yang tidak atau melakukan penundaan dalam membayar pajak yang sudah menjadi kewajibannya. Berdasarkan penelitian yang dilakukan oleh Indry (2013), rasio pencairan tunggakan pajak berpengaruh terhadap penerimaan pajak penghasilan orang pribadi. Bila tunggakan piutang pajak terjadi karen kelalaian wajib pajak dalam melunasi utang pajaknya, maka secara tidak 
langsung akan mengurangi penerimaan pajak (Cahya : 2013).

\section{KAJIAN TEORI DAN}

\section{PENGEMBANGAN HIPOTESIS}

Teori yang dijadikan dasar dalam penelitian ini salah satunya adalah Tero

Gaya Pikul. Mardiasmo (2011) membahas tentang Teori Gaya Pikul yang menyatakan bahwa beban pajak untuk semua orang harus sama beratnya, artinya pajak harus dibayar sesuai dengan daya pikul masingmasing orang. Resmi (2011) mengatakan dasar keadilan pemungutan pajak terletak pada jasajasa yang diberikan oleh negara kepada warganya, yaitu perlindungan atas jiwa dan harta bendanya.Untuk kepentingan tersebut diperlukan biaya-biaya yang harus dipikul oleh segenap orang yang menikmati perlindungan itu, yaitu dalam bentuk pajak.

Teori ini menunjukkan bahwa asas keadilan perlu diperhatikan, dalam hal ini tentang pembebanan pajak pada setiap orang. Setiap orang harus memikul pajak harus dengan kemampuan yang sama. Pembayaran pajak haruslah sesuai dengan kemampuan gaya pikul seseorang dengan memperhitungkan pengeluaran atau pembiayaan seseorang. Dalam pajak penghasilan orang pribadi, gaya pikul untuk pengeluaran atau pembiayaan disebut sebagai penghasilan yang tidak dikenakan pajak (PTKP).

2.1. Ekstensifikasi Pajak dan Penerimaan Pajak Penghasilan Orang Pribadi

Menurut Oktaviani (2010:2) dalam Wella (2013), ekstensifikasi seharusnya sama sekali tidak membebani Wajib

Pajak dengan jumlah pajak yang lebih besar dari yang seharusnya terutang berdasarkan peraturan, melainkan upaya untuk menumbuhkan kesadaran berpajak bagi mereka yang telah menerima penghasilan diatas PTKP dengan mendaftarkan diri dan memperoleh NPWP serta membayar dan melaporkan secara jujur berapa 
besarnya pajak terutangnya. Menurut

Wella (2013), ekstensifikasi pajak

dapat berpengaruh terhadap

penerimaan pajak penghasilan orang

pribadi jika dilakukan dengan efisien,

optimal, dan tepat sasaran. Jumlah

wajib pajak baru yang terus meningkat

secara logika akan menambah jumlah

penerimaan pajak penghasilan. Menurut

Widdyah, dkk (2013), dengan

keefektifan ekstensifikasi yang

dilakukan akan berdampak positif

terhadap penerimaan pajak penghasilan.

Penelitian sebelumnya yang

menyatakan ekstensifikasi pajak

berpengaruh terhadap penerimaan

pajak penghasilan orang pribadi adalah

Vergina dan Juwita (2013).

$\mathbf{H}_{1}$ : Ekstensifikasi pajak berpengaruh terhadap penerimaan pajak penghasilan orang pribadi.

2.2. Kepatuhan Wajib Pajak

Berpengaruh Terhadap Penerimaan

Pajak Penghasilan Orang Pribadi.

Ekstensifikasi dan upaya lain yang

dilakukan pemerintah akan percuma jika tidak ada kepatuhan dari sisi wajib

pajaknya. Menurut Divianto (2013),

kepatuhan wajib pajak secara

signifikan mempengaruhi penerimaan

pajak penghasilan. Seorang ahli

ekonomi (Sarker: 2003) mengatakan

bahwa kepatuhan wajib pajak dapat

diartikan sebagai derajat wajib pajak

untuk melaksanakan aturan perpajakan

dengan baik dan benar (atau tidak

benar). Sehingga semakin tingginya

tingkat kepatuhan maka peraturan

perpajakan akan dijalankan dengan

semakin baik dan benar, begitu juga

sebaliknya apabila tingkat kepatuhan

rendah.

Dalam penggunaan informasi

akuntansi dibutuhkan suatu

pemahaman terkait akuntansi tersebut.

Karena akuntansi merupakan suatu

ilmu yang mengharuskan

penggunanya mengerti dan memahami

bagaimana akuntansi tersebut dibuat

dan digunakan. Tingkat pemahaman

akuntansi seorang pemilik usaha atau

manajer akan terlihat dari bagaimana

seorang manajer dalam mengelola 
keuangan perusahaannya (Nurmala, 2014). Oleh karena itu tiap perusahaan akan berbeda-beda dalam pengelolaan keuangannya, dengan begitu peneliti tertarik untuk mengangkat pemahaman akuntansi untuk dijadikan variabel bebas penelitian.

Penelitian

sebelumnya

menunjukkan bahwa kepatuhan wajib

pajak berpengaruh terhadap

penerimaan pajak penghasilan orang pribadi yaitu Divianto (2013).

$\mathbf{H}_{2}$ : Kepatuhan wajib pajak berpengaruh terhadap penerimaan pajak penghasilan orang pribadi.

2.3. Pencairan Tunggakan Pajak Berpengaruh Terhadap Penerimaan Pajak Penghasilan Orang Pribadi.

Menurut Kurniawan (2006:1) Pengertian utang pajak adalah sejumlah pajak berupa sanksi administrasi bunga, denda, atau kenaikan yang masih jadi kewajiban wajib pajak untukmembayarnya yang tercantum dalam surat ketetapan pajak atau surat sejenisnya berdasarkan ketentuan umum dan tatacara perpajakan. Dalam Mardiasmo (2011:125), Penagihan pajak adalah serangkaian tindakan agar penanggung Pajak melunasi utang pajak dan biaya penagihan pajak dengan mengukur atau memperingatkan, melaksanakan penagihan seketika dan sekaligus, memberitahukan surat paksa, mengusulkan pencegahan, melaksanakan penyitaan, melaksanakan penyanderaan, menjual barang yang telah disita. Piutang pajak dengan jumlah yang besar dapat menghambat penerimaan pajak, oleh karena itu harus dilakukan tindakan untuk meminimalisir tunggakan pajak tersebut.Semakin besar rasio pencairan tunggakan pajak maka semakin besar pula jumlah penerimaan $\mathrm{PPh}$ Orang Pribadi yang diterima (Indry:2013).

Penelitian sebelumnya yang menunjukkan bahwa pencairan tunggakan pajak berpengaruh terhadap penerimaan pajak penghasilan orang pribadi adalah Kukuh (2014) dan 
Aurelia (2014) H3 $_{3}$ : Pencairan tunggakan pajak berpengaruh terhadap penerimaan pajak penghasilan orang pribadi

\section{METODE PENELITIAN}

\subsection{Jenis dan Sumber Dana}

Jenis data yang digunakan pada penelitian ini adalah data sekunder. Sumber data diperoleh dari Kantor Pelayanan Pajak Pratama Jakarta Duren Sawit. Adapun data yang digunakan adalah data tahun 2012-2014 per bulan terkait dengan: Jumlah wajib pajak orang pribadi yang terdaftar baru, Jumlah Surat Pemberitahuan (SPT) Masa PPh 21 yang dilaporkan setiap bulannya, Jumlah pencairan tunggakan pajak dan saldo tunggakan pajak di awal tahun, Jumlah penerimaan pajak penghasilan orang Pribadi

\subsection{Variabel Penelitian}

Variabel dependen adalah Penerimaan pajak penghasilan orang pribadi. Variabel ini diproksikan dengan melihat jumlah penerimaan pajak yang bersumber dari pajak penghasilan pasal 21 orang pribadi setiap bulannya pada tahun 2012-2014. Variabel independen adalah ekstensifikasi pajak, kepatuhan wajib pajak, dan pencairan tunggakan pajak

\subsection{Metode Analisis Data}

$$
\text { Pengukuran masing-masing }
$$

variabel tersebut adalah sebagai

berikut:

1. Jumlah wajib pajak orang pribadi yang terdaftar baru setiap bulan.

2. Jumlah Surat Pemberitahuan (SPT) Masa PPh 21 yang dilaporkan setiap bulan.

3. Rasio perbandingan jumlah pencairan tunggakan pajak dengan saldo tunggakan pajak.

Pengujian hipotesis menggunakan regresi linear berganda. Model regresi dari penelitian ini adalah sebagai berikut :

$$
\mathrm{Y}=\alpha+\beta_{1} \mathrm{EKS}+\beta_{2} \mathrm{KEP}+\beta_{3} \mathrm{PTP}+\varepsilon
$$

$$
\text { Uji asumsi klasik dilakukan }
$$

sebelum uji regresi linear bergada, yaitu uji normalitas, multikolinearitas, autokorelasi, dan heteroskedastisitas. 
HASIL PENELITIAN

Pada tabel IV.1
deskriptif terlihat
penambahan wajib pajak terdaftar
yaitu 831 orang per bulan dengan nilai
minilam 242 orang. Hasil ini
menunjukkan bahwa ekstensifikasi
yang dilakukan cukup optimal.

Hasil dari analisis statistik deskriptif juga menggambarkan variabel kepatuhan wajib pajak dengan nilai minimum sebanyak 2392 wajib pajak yang melaporkan SPT Masa PPh 21 sementara nilai maksimum 3257 SPT, ini juga merupakan jumlah yang tidak sedikit dan menunjukkan bahwa wajib pajak yang terdaftar di KPP Pratama Jakarta Duren Sawit tergolong patuh.

Untuk variabel rasio pencairan tunggakan pajak dengan nilai minimum 0,0008 dan nilai maksimum 0,0358 , sementara nilai rata-rata rasio pencairan yaitu 0,105 atau $1 \%$ per bulan. Hasil ini menunjukkan nilai pencairan tunggakan yang masih tergolong rendah.

Hasil uji t yang disajikan dalam tabel IV.2, terlihat bahwa penambahan WP memiliki nilai Thitung sebesar 2,283 lebih besar dari Ttabel 2,0369 dengan tingkat signifikansi 0,029 lebih kecil daripada tingkat signifikansi yang ditolerir yaitu $5 \%$ atau 0,05 . Hal ini menyiratkan bahwa Ho ditolak sehingga hipotesis diterima. Dapat disimpulkan bahwa variabel independen penambahan WP secara parsial berpengaruh terhadap penerimaan pajak penghasilan Orang Pribadi. Maka Hipotesis pertama (H1) yang menyatakan ekstensifikasi pajak berpengaruh terhadap penerimaan pajak penghasilan Orang Pribadi terbukti.

Tabel IV.2 terlihat bahwa jumlah SPT memiliki Thitung sebesar 2,407 lebih besar dari Ttabel dengan tingkat signifikansi 0,022 lebih kecil dari tingkat signifikansi yang ditolerir yaitu sebesar 0,05 yang menyiratkan bahwa Ho ditolak dan Ha diterima. Dapat disimpulkan bahwa variabel 
independen lain yaitu kepatuhan wajib

pajak secara parsial berpengaruh

terhadap penerimaan pajak penghasilan

Orang Pribadi. Maka Hipotesis kedua

(H2) yang menyatakan bahwa

kepatuhan wajib pajak berpengaruh

terhadap penerimaan pajak penghasilan

Orang Pribadi terbukti.

Tabel IV.2 dapat dilihat bahwa pencarian tunggakan pajak memiliki Thitung -0,361 yang lebih kecil daripada Ttabel dengan tingkat signifikansi 0,720 lebih besar dari tingkat signifikansi yang ditolerir 0,05 . Hal ini menyiratkan bahwa Ho diterima dan Ha ditolak. Dapat disimpulkan bahwa variabel independen lain yaitu pencairan tunggakan pajak secara parsial tidak berpengaruh terhadap penerimaan.

pajak penghasilan Orang Pribadi.

Maka hipotesis ketiga (H3) yang menyatakan pencairan tunggakan pajak berpengaruh terhadap penerimaan pajak penghasilan Orang Pribadi tidak terbukti. Sementara itu, pada tabel IV.3 dapat terlihat hasil adjusted $\mathrm{R}^{2}$ dari variabel-variabel bebas dalam penelitian ini adalah sebesar 0,332 . Hal ini berarti bahwa $33,2 \%$ dari penerimaan pajak penghasilan Orang Pribadi dipengaruhi oleh variabelvariabel bebas dalam penelitian ini, sedangkan $66,8 \%$ lainnya dijelaskan oleh faktor lainnya diluar model regresi. Dalam hal ini faktor lain yang tidak dijelaskan dalam penelitian ini yang dapat berpengaruh langsung terhadap penerimaan pajak penghasilan Orang Pribadi yaitu misalnya sosialisasi perpajakan, jumlah wajib pajak, intensifikasi, pertumbuhan ekonomi, dan faktor lainnya.

\section{KESIMPULAN, SARAN DAN \\ KETERBATASAN PENELITIAN}

Hasil penelitian ini menunjukkan secara kuantitatif bahwa ekstensifikasi pajak berpengaruh terhadap penerimaan pajak penghasilan orang pribadi. Karena semakin banyak wajib pajak bertambah setiap bulannya akan menambah penerimaan pajak oleh KPP yang didapatkan dari pajak penghasilan 
orang pribadi. Kepatuhan wajib pajak berpengaruh terhadap penerimaan pajak penghasilan orang pribadi menurut penelitian ini. hal ini menunjukkan bahwa semakin patuh atau semakin banyak wajib pajak yang patuh terhadap pajak, maka akan menambah penerimaan pajak penghasilan orang pribadi. Sedangkan untuk pencairan tunggakan pajak, tidak berpengaruh terhadap penerimaan pajak penghasilan orang pribadi.

Hasil penelitian tentang pengaruh ekstensifikasi pajak, kepatuhan wajib pajak, dan pencairan tunggakan pajak terhadap penerimaan pajak penghasilan orang pribadi merupakan bukti bahwa dua variabel diantaranya yaitu ekstensifikasi pajak dan kepatuhan wajib pajak merupakan hal yang penting dalam meningkatkan penerimaan pajak penghasilan orang pribadi. Ekstensifikasi pajak dan kepatuhan wajib pajak terbukti secara kuantitatif berpengaruh terhadap penerimaan pajak penghasilan orang pribadi di KPP Pratama Jakarta Duren Sawit berdasarkan data setiap bulannya pada tahun 2012-2014. Penerimaan pajak penghasilan khususnya untuk penghasilan orang pribadi mempunyai peran yang cukup penting dalam penerimaan pajak yang digunakan untuk membangun negara. Berbagai kegiatan dilakukan oleh Direktorat Jenderal Pajak (DJP) untuk memaksimalkan penerimaan pajak. Salah satunya adalah ekstensifikasi pajak yang merupakan upaya untuk menambah jumlah wajib pajak. Hal ini perlu diperhatikan agar wajib pajak terus bertambah dengan tujuan wajib pajak tersebut memenuhi kewajibannya sebagai wajib pajak.

Tentunya upaya tersebut juga tidak bisa lepas dari kepatuhan wajib pajak itu sendiri. Sosialisasi dan penyuluhan kepada wajib pajak tentang kewajiban wajib pajak sangat dibutuhkan untuk memaksimalkan penerimaan pajak penghasilan. Hal yang perlu diperhatikan juga oleh pihak Direktorat Jenderal Pajak (DJP) 
agar menambah jumlah juru sita agar

kegiatan penagihan dapat berjalan

dengan optimal sehingga efektif dalam

pengurangan piutang pajak negara.

Bagi peneliti selanjutnya, peneliti menyarankan untuk memperluas sampel dari beberapa KPP dan menambah jumlah tahun observasi agar hasil yang didapatkan bisa lebih menjelaskan kondisi secara umum. Kemudian untuk pengukuran variabel kepatuhan juga bisa menggunakan jumlah STP (Surat Tagihan Pajak), dan juga dapat menambah variabel yang memungkinkan mempengaruhi penerimaan pajak penghasilan misalnya intensifikasi pajak atau kesadaran wajib pajak. 


\section{REFERENSI}

Adriani, Wella. Pengaruh Ekstensifikasi Pajak Dan Tingkat Kepatuhan Wajib Pajak Orang Pribadi Terhadap Tingkat Penerimaan Pajak Penghasilan Pada Kantor Pelayanan Pajak (Pratama) Kota Tanjungpinang. Jurusan Akuntansi Fakultas Ekonomi Universitas Maritim Raja Ali Haji (UMRAH) Tanjungpinang. 2013.

Divianto.Pengaruh Kepatuhan Wajib Pajak Orang Pribadi Terhadap Penerimaan Pajak Penghasilan KPP Pratama Baturaja. Jurnal Ekonomi Dan Informasi Akuntansi (Jenius). Vol. 3 No. 3. September 2013

Fitriani, Dina Dan Putu Mahardika. Analisa Faktor-Faktor Yang Mempengaruhi Jumlah Penerimaan Pajak Penghasilan Orang Pribadi (Studi Kasus Di Wilayah Kerja Kantor Jurnal IImiah Wahana Akuntansi Volume 10, No.2, Tahun 2015
Pelayanan Pajak Batu). Journal Of Indonesian Applied Economics. Vol. 3 No. 2 Oktober 2009, 135-149

Ghozali, Imam. Aplikasi Analisis Multivariate dengan program SPSS, Badan Penerbit Universitas Diponegoro, Semarang : 2009

Hajat, Nurahma. Pedoman Penulisan Skripsi Sarjana. Jakarta: Fakultas Ekonomi Universitas Negeri Jakarta. 2012. Hasibuan, Indry Anggina. Faktor-Faktor Yang Mempengaruhi Jumlah Penerimaan Pajak Penghasilan Orang Pribadi Di KPP Pratama Padang. 2013.

Jonker., Metode Penelitian. Jakarta :

Salemba Empat. 2011

Juniardi, Kukuh Putranda, Siti Ragil Handayani, dan Devi Farah Azizah. Pengaruh Surat Ketetapan Pajak dan Tindakan 
Penagihan Aktif terhadap

Pencairan Tunggakan Pajak

Penghasilan Badan. Jurnal

Administrasi Bisnis (JAB). Vol.

17 No. 1 Desember 2014

Kurniawan, Panca dan Bagus

Pamungkas. Penagihan Pajak .

Malang: Bayu Media. 2006

Mardiasmo. Perpajakan Edisi Revisi

2011.Yogyakarta : Andi. 2011

Molle, Aurelia Indah, Sifrid

Pangemanan, dan Harijanto

Sabijono. Analisis Faktor-Faktor

Yang Mempengaruhi

Penerimaan Pajak Penghasilan

Wajib Pajak Orang Pribadi

Pada Kpp Pratama Manado.

$\begin{array}{lll}\text { Jurnal } & \text { EMBA.Vol.2 No.4 }\end{array}$

Desember 2014, Hal. 108-115

Muhidin, Sambas Ali. Analisis Korelasi,

Regresi, dan Jalur dalam

Penelitian. Bandung : Pustaka

Setia. 2011

Peraturan Menteri Keuangan nomor

Jurnal IImiah Wahana Akuntansi

Volume 10, No.2, Tahun 2015
PMK-162/PMK.011/2012

Purwono, Herry. Dasar-Dasar Perpajakan dan Akuntansi

Pajak. Jakarta: Erlangga. 2010.

Resmi, Siti. Perpajakan - Teori

dan Kasus. Jakarta : Salemba Empat. 2011.

Suandy, Erly. Perpajakan. Jakarta : Salemba Empat. 2002. Sugiyono. Statistika untuk Penelitian. Bandung : Alfabeta. 2012

Sukmawati, Widdyah, Darminto, dan Devi Farah Azizah. Efektivitas Pelaksanaan Ekstensifikasi Wajib Pajak Melalui Pemberian Nomor Pokok Wajib Pajak (Npwp) Dalam Rangka Meningkatkan

Penerimaan Pajak Penghasilan. 2013.

Umar, Husein. Metode Penelitian untuk Skripsi dan Tesis Bisnis. Edisi Kedua. Jakarta: Rajawali Pers. 2011 
Undang-Undang Nomor 16 tahun 2009

Undang-Undang Pajak Penghasilan

Nomor 36 Tahun 2008

Undang-Undang Republik Indonesia

Nomor 28 Tahun 2007 tentang Ketentuan

Umum Dan Tata Cara Perpajakan

Undang-Undang Nomor 27 Tahun 2014

Vergina, dan Ratna Juwita. Pengaruh

Ekstensifikasi dan Intensifikasi

Terhadap Penerimaan Pajak

Penghasilan Orang Pribadi di

Kantor Pelayanan Pajak

Pratama Palembang Ilir Barat.

2012

Waluyo. Perpajakan Indonesia.

Jakarta: Salemba Empat. 2011 